\title{
MIRC reactions using sulfoxides and synthesis of dictyopterene $A$
}

\author{
Mike Casey, ${ }^{* a}$ Claire M. Keaveney, ${ }^{a}$ and Andrew J. Walker ${ }^{b}$ \\ ${ }^{a}$ Chemistry Department, the Centre for Synthesis and Chemical Biology, and the Conway \\ Institute of Biomolecular and Biomedical Research, University College Dublin, Dublin 4, \\ Ireland \\ ${ }^{b}$ Department of Chemistry and Applied Chemistry, University of Salford, Salford M5 4WT, \\ United Kingdom \\ E-mail:mike.casey@ucd.ie
}

\section{Dedicated to Professor Charles W. Rees on the occasion of his $75^{\text {th }}$ birthday}

(received 26 Jun 02; accepted 02 Aug 02; published on the web 10 Aug 02)

\begin{abstract}
Michael initiated ring closure reactions, using alkyl imidazolyl sulfoxides as nucleophiles, provided a 2-substituted cyclopropanecarboxylate 2 and cyclohexanecarboxylate 5, with high yields and excellent diastereoselectivity. Thermal elimination of the imidazolylsulfinyl group gave an alkene 3 . This method was used to carry out a short synthesis of dictyopterene A. A 2hexenylcyclopropanecarboxylate 13 was prepared using a MIRC reaction of hexyl 1-methyl-2imidazolyl sulfoxide with 4-bromocrotonate, followed by pyrolytic elimination of the imidazolylsulfinyl group. Straightforward conversion of the ester group into a vinyl group furnished dictyopterene A.
\end{abstract}

Keywords: MIRC reactions, sulfoxides, dictyopterene A, conjugate addition

\section{Introduction}

The term MIRC (Michael Initiated Ring Closure) was first used by Little and Dawson to describe the reactions which involve (i) nucleophilic conjugate addition to a Michael acceptor, and (ii) ring closure of the resulting enolate. ${ }^{1}$ Many interesting and synthetically useful examples have been reported. ${ }^{2}$ We now describe the use of sulfoxide-stabilised carbanions as nucleophiles in MIRC reactions, along with an application to stereoselective natural product synthesis. The use of sulfoxide-stabilised carbanions as chiral carbon nucleophiles is a very useful strategy for stereoselective synthesis. $^{3}$

The first ever report of a diastereoselective conjugate addition reaction of a sulfoxidestabilised carbanion involved a MIRC reaction using a benzyl sulfoxide. ${ }^{4}$ Recently, Toru and 
coworkers showed that enantiopure p-tolyl 2-trimethylsilylethyl sulfoxide could be used to prepare several cyclic products via highly diastereoselective MIRC reactions. ${ }^{5}$ However, the scope of their method is somewhat restricted by the requirement that the trimethylsilyl group be present. We have conducted an extensive study of conjugate reactions of sulfoxide-stabilised carbanions and have shown that high diastereoselectivity can be achieved using appropriate nonacidic "spectator" groups on the sulfoxides. ${ }^{6}$ In an extension of that work, we now report the results of a preliminary study of MIRC reactions of alkyl imidazolyl sulfoxides

\section{Results and Discussion}

\section{MIRC Reactions}

We first carried out some model studies to determine the scope of the process, beginning with "Type I" MIRC reactions, in which the alkylating agent is attached to the Michael acceptor. We had earlier found that conjugate additions of alkyl sulfoxides gave high yields when 2-pyridyl or 1-methyl-2-imidazolyl spectator groups were used. ${ }^{6 c}$ Excellent diastereoselectivity was obtained provided that hexamethyldisilazide bases were used. Hence, the MIRC reactions were carried out using1-methyl-2-imidazolyl sulfoxides. The imidazolyl phenethyl sulfoxide 1 was deprotonated using LiHMDS and reacted with methyl 4-bromocrotonate at $-78{ }^{\circ} \mathrm{C}$ over $20 \mathrm{~min}$. Work-up and chromatography afforded the desired cyclopropane 2 in $86 \%$ yield, as a single diastereomer (Scheme 1). The relative stereochemistry at the new centres $\alpha$ and $\beta$ to the sulfur was assigned by analogy with earlier conjugate addition results. ${ }^{6 c}$ The trans stereochemistry of the disubstituted cyclopropane ring was assigned by interpretation of the ${ }^{1} \mathrm{H}$ coupling constants (each ring hydrogen had one cis coupling constant of $c a .8 \mathrm{~Hz}$ and two trans/geminal coupling constants of 4-6 Hz), and by analogy with numerous precedents for trans-cyclopropane formation in MIRC reactions. ${ }^{2}$ An attractive feature of the use of sulfoxides is the availability of several useful transformations of the products. ${ }^{6 \mathrm{~d}, 7}$ For example, product 2 underwent smooth thermal elimination at $61{ }^{\circ} \mathrm{C}$ over 5 hours to afford the $(E)$-alkene 3 in high yield. The use of the electron-withdrawing heteroaryl spectator group significantly reduces the temperature required for the elimination reaction. ${ }^{7 b}$
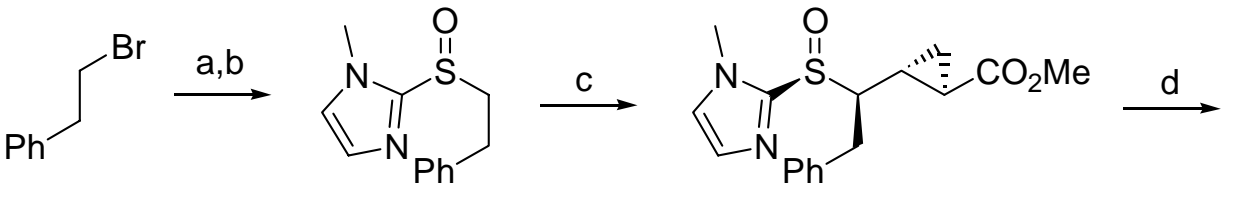

1 2

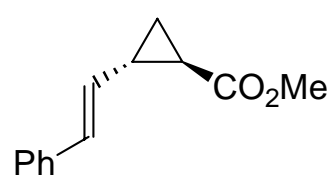

3

Scheme 1. (a) 1-Methyl-2-imidazolinethiol, $\mathrm{K}_{2} \mathrm{CO}_{3}$, acetone, reflux. (b) $\mathrm{mCPBA}, \mathrm{CH}_{2} \mathrm{Cl}_{2}, 0{ }^{\circ} \mathrm{C}$, $81 \%$ over 2 steps. (c) LiHMDS, THF, $-78{ }^{\circ} \mathrm{C}$; methyl 4-bromocrotonate, THF, $-78{ }^{\circ} \mathrm{C} ; \mathrm{NH}_{4} \mathrm{Cl}$, $86 \%$. (d) $\mathrm{CHCl}_{3}$, reflux, $82 \%$. 
Preparation of a six-membered ring was also studied. This required the synthesis of methyl 7iodoheptenoate $4,{ }^{8}$ which was obtained from dihydropyran in excellent overall yield using straightforward transformations (Scheme 2). Addition of the imidazolyl sulfoxide 1 to the iodide 4 proceeded very smoothly to afford the cyclohexane 5 in $68 \%$ isolated yield as a single diastereomer). Thus, MIRC reactions using alkyl imidazolyl sulfoxides as nucleophiles provide three- and six-membered rings, with high yields, and excellent diastereoselectivity, and further extension of the scope will, no doubt, be possible. The stereochemistry of the cyclohexanecarboxylate 5 was assigned on the basis of the diaxial coupling of the proton $\alpha$ - to the ester $(\delta 2.50,1 \mathrm{H}, \mathrm{dt}, \mathrm{J}=3.5,11.5 \mathrm{~Hz})$. The same product could, in principle, be obtained via conjugate addition to a cyclohenecarboxylate ester, but earlier work had shown that the conjugate addition of a tert-butyl sulfoxide to methyl tiglate proceeded in very low yield, ${ }^{6 a}$ so the MIRC reaction is the only viable route to products of this kind.

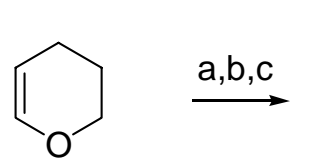

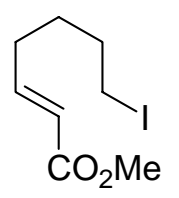

4
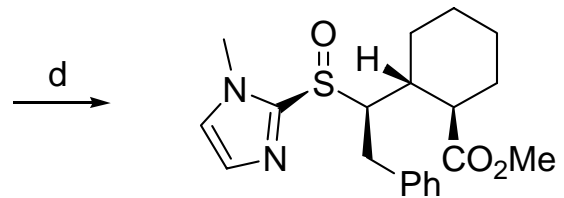

5

Scheme 2. (a) $\mathrm{HCl}, \mathrm{H}_{2} \mathrm{O}$. (b) $\mathrm{Ph}_{3} \mathrm{PCHCO}_{2} \mathrm{Me}$, THF, reflux. (c) $\mathrm{Ph}_{3} \mathrm{P}, \mathrm{I}_{2}$, imidazole, $\mathrm{CH}_{2} \mathrm{Cl}_{2}, 82 \%$ over 3 steps. (d) LiHMDS, THF, $-78^{\circ} \mathrm{C} ; \mathbf{1}$, THF, $-78{ }^{\circ} \mathrm{C} ; \mathrm{NH}_{4} \mathrm{Cl}, 68 \%$.

A brief study of "Type II" MIRC reactions, in which the alkylating agent is attached to the nucleophile, was also carried out. Deprotonation of the 3-chloropropyl sulfoxide 6 using LiHMDS, in the presence of methyl crotonate, rapidly gave a new product, but the spectroscopic data showed that it was the cyclopropane 7 (Scheme 3). There was no trace of 1,4-adduct, or of the desired cyclopentane, indicating that the cyclisation of the sulfoxide-stabilised anion was much faster than reaction with the crotonate. As expected, treatment of the sulfoxide 6 with LiHMDS the absence of crotonate gave the cyclopropane in high yield.

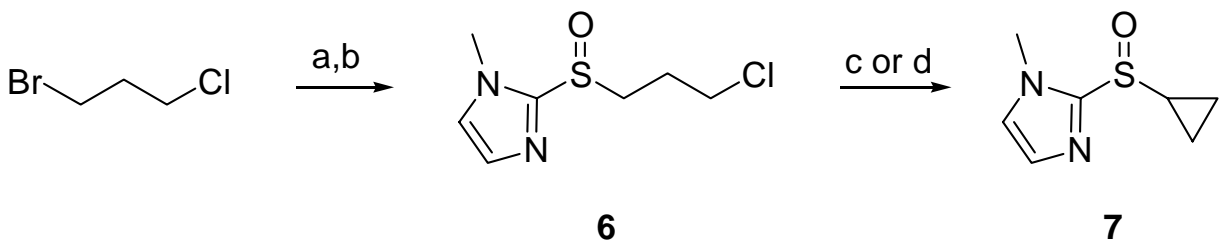

Scheme 3. (a) 1-Methyl-2-imidazolinethiol, $\mathrm{K}_{2} \mathrm{CO}_{3}$, acetone, reflux, 99\%. (b) $\mathrm{mCPBA}, \mathrm{CH}_{2} \mathrm{Cl}_{2}$, $0{ }^{\circ} \mathrm{C}, 60 \%$. (c) NaHMDS, methyl 4-bromocrotonate, THF, $-78{ }^{\circ} \mathrm{C} ; \mathrm{NH}_{4} \mathrm{Cl}, 47 \%$. (d) LiHMDS, THF, $-78^{\circ} \mathrm{C} ; \mathrm{NH}_{4} \mathrm{Cl}, 87 \%$. 
The analogous 4-chlorobutyl sulfoxide 8 was then prepared, in the expectation that cyclobutane formation would be much slower (Scheme 4). Deprotonation and addition to methyl crotonate did give the conjugate adduct $\mathbf{9}$, rather than the cyclobutyl sulfoxide, but all efforts to bring about cyclisation to the desired cyclohexanecarboxylate $\mathbf{1 0}$ were unsuccessful. For example, warming of the reaction mixture to $0{ }^{\circ} \mathrm{C}$, use of KHMDS rather than LiHMDS, addition of HMPA or $\mathrm{KOBu}^{t}$ to the reaction mixture, and attempting the cyclisation of isolated conjugate adduct 9, all failed to bring about intramolecular enolate alkylation by the alkyl chloride. Efforts were then directed toward the preparation of the analogous 4-bromobutyl sulfoxide, but these were stymied by the formation of polar materials, presumably cyclic sulfonium salts formed by intramolecular S-alkylation of the desired sulfoxide and the sulfide precursor. Although we did not succeed in effecting Type II MIRC reactions, they are of interest because they may yet provide useful new annulation strategies.

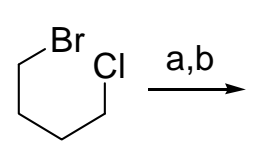

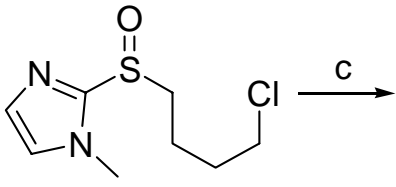

8

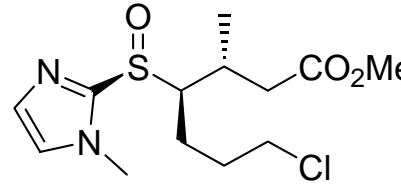

9

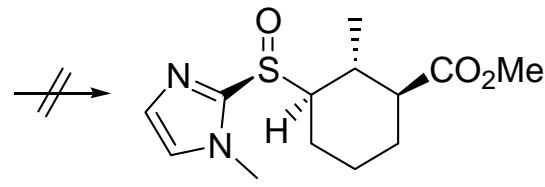

10

Scheme 4. (a) 1-Methyl-2-imidazolinethiol, $\mathrm{K}_{2} \mathrm{CO}_{3}$, acetone, reflux. (b) $\mathrm{NaIO}_{4}, \mathrm{MeOH}, \mathrm{H}_{2} \mathrm{O}, 0{ }^{\circ} \mathrm{C}$, $60 \%$ over 2 steps. (c) LiHMDS, THF, $-78^{\circ} \mathrm{C}$; methyl crotonate, THF, $-78{ }^{\circ} \mathrm{C} ; \mathrm{NH}_{4} \mathrm{Cl}, 48 \%$.

Synthesis of dictyopterene A. The preliminary study showed that alkyl imidazolyl sulfoxides undergo efficient diastereoselective Type I MIRC reactions, which show considerable promise as a synthetic tool. To demonstrate this synthetic potential, a synthesis of $( \pm)$-dictyopterene A was undertaken. The dictyopterenes are sexual pheromones for several species of seaweed, and dictyopterene A, trans-1-(1-hexenyl)-2-vinylcyclcopropane, $\mathbf{1 6}$ is responsible for the characteristic "ocean" smell of these algae. ${ }^{9}$ Several syntheses of dictyopterene A have been reported. ${ }^{10}$ It was decided to prepare an hexenylcyclopropanecarboxylate using a Type I MIRC reaction, followed by pyrolytic elimination of the imidazolylsulfinyl group. Straightforward modification of the ester was then expected to provide dictyopterene A.

The required sulfoxide 11 was prepared using the conventional method in $87 \%$ yield (Scheme 5). The MIRC reaction with (E)-methyl 4-bromocrotonate furnished the desired transdisubstituted cyclopropane $\mathbf{1 2}$ in $71 \%$ yield as a single diastereomer. Thermal elimination of the sulfinyl moiety was found to require relatively harsh conditions. Thus, refluxing the sulfoxide $\mathbf{1 2}$ and $\mathrm{K}_{2} \mathrm{CO}_{3}$ in toluene for 30 hours afforded an inseparable geometric mixture of alkenes 13 (E/Z ca. $5 / 1$ by ${ }^{1} \mathrm{H}$ NMR) in $90 \%$ yield (Scheme 5). Addition of $\mathrm{K}_{2} \mathrm{CO}_{3}$ to the reaction mixture was found to be essential for clean alkene formation. Presumably, its role is to scavenge the sulfenic acid byproduct. The poor geometric purity may reflect the high temperature required to effect the elimination at a synthetically useful rate and the relatively small size of the cyclopropyl group. 
Reduction of the ester 13 using $\mathrm{LiAlH}_{4}$ gave the alcohol 14 in quantitative yield. The synthesis was completed by following literature precedents. Oxidation with PCC gave the known aldehyde $15^{10 \mathrm{i}, \mathrm{k}}$ in $94 \%$ yield. A Wittig reaction using methylene-triphenylphosphorane, followed by careful distillation of the crude product afforded $( \pm$ )-dictyopterene A 16, as a very odourous volatile oil in poor yield (25\%). The ${ }^{1} \mathrm{H}$ NMR spectrum showed that the sample was contaminated with hexamethyldisilazane (LiHMDS was used to generate the phosphorane), but the data for the major product were in excellent agreement with those reported for dictyopterene A. ${ }^{9,10}$ The product was obtained as a $c a .5: 1$ mixture of $E$ and $Z$ isomers. The yield of final step was disappointing, due principally to the difficulty of isolating the volatile product on a small scale. However, good yields for this step have been recorded by others, ${ }^{10 i, k}$ so, having proven the structure of our product, we did not attempt to optimise the procedure.

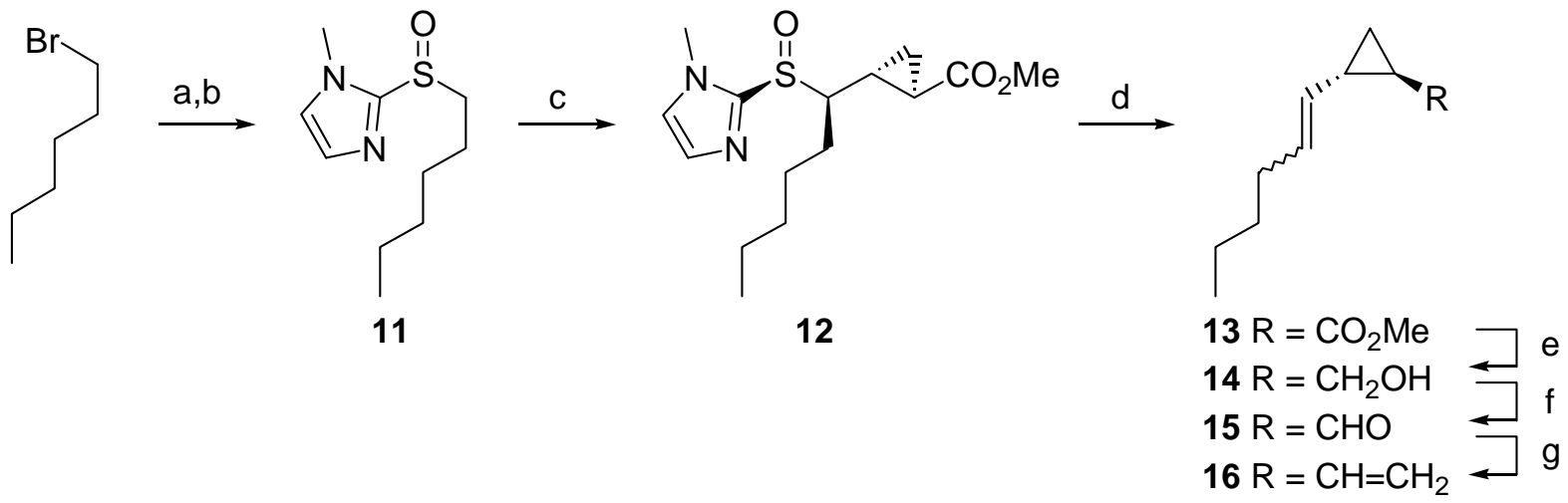

Scheme 5. (a) 1-Methyl-2-imidazolinethiol, $\mathrm{NaOH}, \mathrm{MeOH}, \mathrm{H}_{2} \mathrm{O}$, reflux. (b) $\mathrm{mCPBA} \mathrm{CH}_{2} \mathrm{Cl}_{2}$, $0{ }^{\circ} \mathrm{C}, 87 \%$ over 2 steps. (c) LiHMDS, THF, $-78{ }^{\circ} \mathrm{C}$; methyl 4-bromocrotonate, THF, $-78{ }^{\circ} \mathrm{C}$; $\mathrm{NH}_{4} \mathrm{Cl}, 72 \%$. (d) Toluene, $\mathrm{K}_{2} \mathrm{CO}_{3}$, reflux, 90\%. (e) $\mathrm{LiAlH}_{4}$, THF, $0{ }^{\circ} \mathrm{C}, 100 \%$. (f) PCC, $3 \mathrm{~A}$ molecular sieve, $\mathrm{CH}_{2} \mathrm{Cl}_{2}, 94 \%$. (g) $\mathrm{Ph}_{3} \mathrm{PMeBr}$, NaHMDS, $\mathrm{Et}_{2} \mathrm{O},-78{ }^{\circ} \mathrm{C}, 25 \%$.

\section{Conclusions}

The results described above indicate that MIRC reactions of alkyl imidazolyl sulfoxides, followed by further transformations of the sulfoxide products, provide an efficient, versatile, and highly diastereoselective route to substituted cycloalkanecarboxylates. This total synthesis of dictyopterene $\mathrm{A}$ is a demonstration of the synthetic potential of this chemistry, and it compares favourably with earlier syntheses of this natural product. The power of this methodology will only be fully realised when enantiopure sulfoxides are used. In that context, it is noteworthy that highly enantioselective methods for the oxidation of imidazolyl ${ }^{11,12}$ and benzimidazolyl ${ }^{12}$ sulfides have been developed. Future efforts will be focused on the use of enantiopure sulfoxides, and the development of Type II MIRC reactions. 


\section{Experimental Section}

General Procedures. Melting points were measured on a Büchi 530 melting point apparatus and are uncorrected. Merck silica gel $60 \mathrm{~F}_{254}$ was used for thin layer chromatography. Merck silica gel 60 (70-230 mesh) was used for flash chromatography. ${ }^{1} \mathrm{H}$ NMR spectra were recorded on a Bruker AC-300, Varian INOVA-300, and Jeol JNM-PMX-270 spectrometers, using $\mathrm{CDCl}_{3}$ as the solvent, with $\mathrm{Me}_{4} \mathrm{Si}$ as an internal reference (0.00). Coupling constants quoted are considered accurate to $\pm 0.3 \mathrm{~Hz}$. Infra-red spectra were recorded on a Perkin-Elmer 1710 Fourier-Transform spectrometer, using $\mathrm{KBr}$ discs for solids and thin films for oils. Mass spectra were recorded on VG Micromass $7070 \mathrm{H}$ and Finnigan 4500 mass spectrometers. Accurate masses were recorded on a Kratos Concept 15 spectrometer. Elemental analyses were determined by Butterworth Laboratories Limited, Middlesex, or in the microanalysis laboratories of the Chemistry Department, UCD. Solvents were dried and distilled according to literature procedures. THF was distilled from benzophenone ketyl immediately prior to use. Dichloromethane and diisopropylamine were distilled from calcium hydride and stored over $4 \AA$ molecular sieve. Petrol refers to petroleum spirits, $40-60{ }^{\circ} \mathrm{C}$ fraction. LiHMDS and NaHMDS were used as supplied by Aldrich Chemical Co.

1-Methyl-2-imidazolyl phenethyl sulfide. A suspension of $\mathrm{K}_{2} \mathrm{CO}_{3}(9.68 \mathrm{~g}, 70.1 \mathrm{mmol}, 1.1$ eq. $)$ in a solution of 1-methyl-2-imidazolinethiol (378) (7.27 g, $63.8 \mathrm{mmol})$ and phenethyl bromide $(11.80 \mathrm{~g}, 63.8 \mathrm{mmol})$ in acetone $(300 \mathrm{~mL})$ was refluxed for $24 \mathrm{~h}$. It was cooled and filtered, and the residue was washed with warm acetone $(2 \times 20 \mathrm{~mL})$. The combined filtrates were concentrated in vacuo to give the crude sulfide as a dark liquid $(14.10 \mathrm{~g}, 64.1 \mathrm{mmol}, 100 \%) .{ }^{1} \mathrm{H}$ NMR (270 MHz, CDCl $): \delta 2.96(2 \mathrm{H}, \mathrm{t}), 3.30(2 \mathrm{H}, \mathrm{t}), 3.52(3 \mathrm{H}, \mathrm{s}), 6.89(1 \mathrm{H}, \mathrm{s}), 7.08(1 \mathrm{H}, \mathrm{s})$, 7.10-7.25 $(5 \mathrm{H}, \mathrm{m})$.

1-Methyl-2-imdazolyl phenethyl (RS)-sulfoxide (1). To a solution of the crude sulfide (13.60 g, $63 \mathrm{mmol})$ in $\mathrm{CH}_{2} \mathrm{Cl}_{2}(100 \mathrm{~mL})$ at $0{ }^{\circ} \mathrm{C}$ was added a solution of meta-chloroperbenzoic acid (15.47 g, nominal 70\%, $63 \mathrm{mmol})$ in $\mathrm{CH}_{2} \mathrm{Cl}_{2}(300 \mathrm{~mL})$ over $3 \mathrm{~h}$. The suspension was stirred for a further $10 \mathrm{~min}$, and filtered, and the residue was washed with $\mathrm{CH}_{2} \mathrm{Cl}_{2}(3 \times 20 \mathrm{~mL})$. The combined organic filtrate was poured into aqueous $\mathrm{NaOH}(500 \mathrm{~mL}, \sim 100 \mathrm{mmol} \mathrm{NaOH})$ and separated. The organic layer was dried $\left(\mathrm{MgSO}_{4}\right)$ and concentrated in vacuo to give the crude sulfoxide, which was subjected to flash column chromatography on silica (EtOAc) to give the title compound 1 as a pale yellow oil $(12.00 \mathrm{~g}, 51.3 \mathrm{mmol}, 81 \%)$. ${ }^{1} \mathrm{H} \mathrm{NMR}\left(300 \mathrm{MHz}, \mathrm{CDCl}_{3}\right): \delta$ $3.07(2 \mathrm{H}, \mathrm{t}, J=7.5 \mathrm{~Hz}), 3.51(1 \mathrm{H}, \mathrm{dt}, J=13,7.5 \mathrm{~Hz}), 3.71(1 \mathrm{H}, \mathrm{dt}, J=13,7.5 \mathrm{~Hz}), 3.87(3 \mathrm{H}, \mathrm{s})$, $6.96(1 \mathrm{H}, \mathrm{d}, J=1 \mathrm{~Hz}), 7.12(1 \mathrm{H}, \mathrm{d}, J=1 \mathrm{~Hz}), 7.16-7.29(5 \mathrm{H}, \mathrm{m}) . v_{\max }: 3107,3028,1497,1456$, 1279, 1040, 759, $701 \mathrm{~cm}^{-1} . \mathrm{m} / \mathrm{z}(\mathrm{CI}): 235\left(\mathrm{M}^{+}+\mathrm{H}, 100 \%\right), 219,130,115,105,83$ (93). HRMS: Calcd for $\mathrm{C}_{12} \mathrm{H}_{14} \mathrm{~N}_{2} \mathrm{OS}: 234.0827$; Found: 234.0822 . 
Methyl(1RS,2RS)-2-[(1RS,SSR)-1-(1-methyl-2-imidazolylsulfinyl)-2-phenylethyl]cyclopropanecarboxylate (2). A solution of the sulfoxide 1 (517 mg, $2.21 \mathrm{mmol})$ in THF (6 mL) was added dropwise to a stirred solution of 1M LiHMDS in THF $(2.43 \mathrm{~mL}, 2.43 \mathrm{mmol})$ in THF $(2.5 \mathrm{~mL})$ at $-78{ }^{\circ} \mathrm{C}$. After $10 \mathrm{~min}$, a solution of methyl 4-bromocrotonate $(90 \%$ tech, $0.32 \mathrm{~mL}$, $2.45 \mathrm{mmol})$ in THF $(1.5 \mathrm{~mL})$ was added dropwise at $-78^{\circ} \mathrm{C}$. After $20 \mathrm{~min}$, the reaction was quenched with saturated aqueous $\mathrm{NH}_{4} \mathrm{Cl}$ solution, and the mixture was warmed to room temperature. The suspension was poured into water and extracted with $\mathrm{CH}_{2} \mathrm{Cl}_{2}(3 \times 30 \mathrm{ml})$, and the combined extracts were dried over $\mathrm{MgSO}_{4}$ and concentrated in vacuo. Chromatography (EtOAc) afforded the title compound 2 as a white solid, mp 97-8 ${ }^{\circ} \mathrm{C}$ (broad, decomp. $70-97{ }^{\circ} \mathrm{C}$ ), (633 mg, $1.91 \mathrm{mmol}, 86 \%) .{ }^{1} \mathrm{H}$ NMR $\left(300 \mathrm{MHz}, \mathrm{CDCl}_{3}\right): \delta 0.38(1 \mathrm{H}, \mathrm{ddd}, J=4.5,6.5,8.5 \mathrm{~Hz})$, $0.90(1 \mathrm{H}, \mathrm{dt}, J=8.5,4.5 \mathrm{~Hz}), 1.03(1 \mathrm{H}, \mathrm{dt}, J=8.5,4.5 \mathrm{~Hz}), 1.37(1 \mathrm{H}, \mathrm{m}), 3.09-3.32(3 \mathrm{H}, \mathrm{m})$, $3.53(3 \mathrm{H}, \mathrm{s}), 3.91(3 \mathrm{H}, \mathrm{s}), 6.98(1 \mathrm{H}, \mathrm{s}), 7.18-7.29(6 \mathrm{H}, \mathrm{m}) . v_{\max }: 3106,3027,2951,1729,1495$, 1453, 1350, 1278, 1210, 1175, 1052, 757, $701 \mathrm{~cm}^{-1} . \mathrm{m} / \mathrm{z}(\mathrm{CI}): 333\left(\mathrm{M}^{+}+\mathrm{H}, 50 \%\right), 131(30), 115$ (90), 83 (100). HRMS: Calcd for $\mathrm{C}_{17} \mathrm{H}_{20} \mathrm{~N}_{2} \mathrm{O}_{3} \mathrm{~S}+\mathrm{H}^{+}: 333.1273$; Found 333.1269.

Methyl trans-2-((E)-2-phenylethenyl)cyclopropanecarboxylate (3). A solution of the sulfoxide $2(100 \mathrm{mg}, 0.30 \mathrm{mmol})$ in $\mathrm{CHCl}_{3}(3 \mathrm{~mL})$ was refluxed for $5 \mathrm{~h}$. It was then concentrated and the residue was chromatographed (4:1 petrol:EtOAc) to afford the title compound 3 (50 mg, $0.248 \mathrm{mmol}, 82 \%) .{ }^{1} \mathrm{H} \mathrm{NMR}\left(300 \mathrm{MHz}, \mathrm{CDCl}_{3}\right): \delta 1.09(1 \mathrm{H}, \mathrm{ddd}, J=4.5,6.2,8.6 \mathrm{~Hz}), 1.47$ $(1 \mathrm{H}, \mathrm{ddd}, J=4.5,5.1,9.5 \mathrm{~Hz}), 1.75(1 \mathrm{H}, \mathrm{ddd}, J=4.0,5.1,8.6 \mathrm{~Hz}), 2.18(1 \mathrm{H}, \mathrm{m}), 3.69(3 \mathrm{H}, \mathrm{s})$, $5.72(1 \mathrm{H}, \mathrm{dd}, J=8.5,16 \mathrm{~Hz}), 6.52(1 \mathrm{H}, \mathrm{d}, J=16 \mathrm{~Hz}), 7.18-7.36(5 \mathrm{H}, \mathrm{m}) . v_{\max }: 3026,2951$, 1728, 1492, 1441, 1397, 1201, 1173, 960, 749, $694 \mathrm{~cm}^{-1} \cdot \mathrm{m} / \mathrm{z}(\mathrm{CI}): 203\left(\mathrm{M}^{+}+\mathrm{H}, 73 \%\right), 220\left(\mathrm{M}^{+}\right.$ $\left.+\mathrm{NH}_{4}, 100\right)$. HRMS Calcd. for $\mathrm{C}_{13} \mathrm{H}_{14} \mathrm{O}_{2}+\mathrm{H}^{+}$: 203.1072; Found 203.1077.

2-Hydroxytetrahydropyran. ${ }^{13}$ A solution of dihydropyran $(10.00 \mathrm{~g}, 119 \mathrm{mmol})$ and $1 \mathrm{~N} \mathrm{HCl}$ $(30 \mathrm{~mL})$ in THF $(120 \mathrm{~mL})$ was stirred at room temperature for $16 \mathrm{~h}$. The mixture was poured into water $(30 \mathrm{~mL})$ and extracted with $\mathrm{CH}_{2} \mathrm{Cl}_{2}(5 \times 30 \mathrm{~mL})$. The combined organic layers were washed with brine, dried, and concentrated in vacuo to give the title compound as a mobile oil (12.00 g, $118 \mathrm{mmol}, 100 \%)$.

Methyl (E)-7-hydroxyhept-2-enoate. ${ }^{14}$ A solution of the crude 2-hydroxytetrahydropyran (7.00 g, $68.6 \mathrm{mmol})$ and carbomethoxymethylenetriphenylphosphorane (23.00 g, $68.9 \mathrm{mmol})$ in THF $(300 \mathrm{~mL})$ was refluxed for $24 \mathrm{~h}$ under nitrogen. The solution was concentrated in vacuo and the residue was diluted with $\mathrm{Et}_{2} \mathrm{O}(150 \mathrm{~mL})$. The resulting suspension was stirred for $30 \mathrm{~min}$, and filtered, and the residue was washed with $\mathrm{Et}_{2} \mathrm{O}(3 \times 20 \mathrm{~mL})$. Concentration of the combined ether phases afforded the title compound, still contaminated with triphenylphosphane oxide, as a yellow oil (15.85 g, $67.2 \mathrm{mmol}, 98 \%),>93 \%(E) .{ }^{1} \mathrm{H}$ NMR $\left(300 \mathrm{MHz}, \mathrm{CDCl}_{3}\right): \delta 1.45-1.63$ $(4 \mathrm{H}, \mathrm{m}), 2.10-2.30(3 \mathrm{H}, \mathrm{m}), 3.58(2 \mathrm{H}, \mathrm{t}, J=6 \mathrm{~Hz}), 3.68(3 \mathrm{H}, \mathrm{s}), 5.78(1 \mathrm{H}, \mathrm{dt}, J=15,1 \mathrm{~Hz}), 6.92$ $(1 \mathrm{H}, \mathrm{dt}, J=15,8 \mathrm{~Hz}) . v_{\max }: 3396,2944,1723,1657,1438,1274,1180,1120,1035 \mathrm{~cm}^{-1} . \mathrm{m} / \mathrm{z}$ (CI): $176\left(\mathrm{M}^{+}+\mathrm{NH}_{4}, 100\right), 159\left(\mathrm{M}^{+}+\mathrm{H}, 10 \%\right)$.

Methyl (E)-7-iodohept-2-enoate (4). ${ }^{8}$ To a solution of $\mathrm{Ph}_{3} \mathrm{P}(195 \mathrm{mg}, 0.74 \mathrm{mmol})$ in $\mathrm{CH}_{2} \mathrm{Cl}_{2}$ $(5 \mathrm{~mL})$ were added imidazole $(51 \mathrm{mg}, 0.74 \mathrm{mmol})$, iodine $(189 \mathrm{mg}, 0.74 \mathrm{mmol})$ (a deep yellow precipitate formed), and a solution of the crude hydroxyheptenoate (151 $\mathrm{mg}, 0.62 \mathrm{mmol})$ in 
$\mathrm{CH}_{2} \mathrm{Cl}_{2}(2 \mathrm{~mL})$. The mixture was stirred at room temperature for $30 \mathrm{~min}$, concentrated in vacuo, and chromatographed (20:1 petrol:EtOAc) to afford the title compound $\mathbf{4}$ as a clear oil (140 mg, $0.52 \mathrm{mmol}, 84 \%) .{ }^{1} \mathrm{H}$ NMR $\left(300 \mathrm{MHz}, \mathrm{CDCl}_{3}\right): \delta 1.50-1.63(2 \mathrm{H}, \mathrm{m}), 1.76-1.86(2 \mathrm{H}, \mathrm{m}), 2.17-$ $2.25(2 \mathrm{H}, \mathrm{m}), 3.16(2 \mathrm{H}, \mathrm{t}, J=6.9 \mathrm{~Hz}), 3.70(3 \mathrm{H}, \mathrm{s}), 5.83(1 \mathrm{H}, \mathrm{dt}, J=15.6,1.5 \mathrm{~Hz}), 6.92(1 \mathrm{H}, \mathrm{dt}$, $J=15.6,7.0 \mathrm{~Hz}) . v_{\max }: 2946,2858,1725,1658,1435,1271,1040,976 \mathrm{~cm}^{-1} . \mathrm{m} / \mathrm{z}(\mathrm{CI}): 286\left(\mathrm{M}^{+}+\right.$ $\left.\mathrm{NH}_{4}, 100 \%\right), 141(33)$.

Methyl (1RS,2RS)-2-[(1RS,SSR)-1-(1-methyl-2-imidazolylsulfinyl)-2-phenylethyl]cyclohexanecarboxylate (5). A solution of the sulfoxide 1 (178 $\mathrm{mg}, 0.76 \mathrm{mmol})$ in THF (4 mL) was deprotonated at $-78^{\circ} \mathrm{C}$ with LiHMDS (nominal 1.0M, $0.92 \mathrm{~mL}, 0.92 \mathrm{mmol}$ ) in THF (2 mL) was reacted with the electrophile $4(245 \mathrm{mg}, 0.91 \mathrm{mmol})$ in THF $(2 \mathrm{~mL})$ at $-78{ }^{\circ} \mathrm{C}$ for $30 \mathrm{~min}$. Workup as for 2 above and chromatography $\left(\mathrm{Et}_{2} \mathrm{O}\right)$ afforded the title compound $\mathbf{5}$ as a white solid, mp $90{ }^{\circ} \mathrm{C}$ (decomp.), residue melted at $116-118{ }^{\circ} \mathrm{C}$, (194 mg, $0.52 \mathrm{mmol}, 68 \%$ ). ${ }^{1} \mathrm{H}$ NMR $\left(300 \mathrm{MHz}, \mathrm{CDCl}_{3}\right): \delta$ 0.80-1.93 $(8 \mathrm{H}, \mathrm{m}), 2.05-2.15(1 \mathrm{H}, \mathrm{m}), 2.50(1 \mathrm{H}, \mathrm{dt}, J=3.5,11.4 \mathrm{~Hz}), 3.02$ $(1 \mathrm{H}, \mathrm{dd}, J=10.8,14.1 \mathrm{~Hz}), 3.37(1 \mathrm{H}, \mathrm{dd}, J=4.3,14.1 \mathrm{~Hz}), 3.46(3 \mathrm{H}, \mathrm{s}), 3.87(3 \mathrm{H}, \mathrm{s}), 3.97(1 \mathrm{H}$, ddd, $J=2.3,4.3,10.8 \mathrm{~Hz}), 6.91(1 \mathrm{H}, \mathrm{s}), 7.09(1 \mathrm{H}, \mathrm{s}), 7.16-7.28(5 \mathrm{H}, \mathrm{m}) . v_{\max }: 2924,1724,1456$, 1162, 1052, 750, $702 \mathrm{~cm}^{-1} \cdot \mathrm{m} / \mathrm{z}(\mathrm{CI}): 375\left(\mathrm{M}^{+}+\mathrm{H}, 10 \%\right), 262$ (55), 245 (20), 115 (70), 83 (100). HRMS Calcd. for $\mathrm{C}_{20} \mathrm{H}_{26} \mathrm{~N}_{2} \mathrm{O}_{3} \mathrm{~S}+\mathrm{H}^{+}: 375.1742$; Found 375.1753.

3-Chloropropyl 1-methyl-2-imidazolyl sulfide. A mixture of 1-methyl-2-imidazolinethiol (2.55 g, $22.4 \mathrm{mmol})$, 1-bromo-3-chloropropane $(2.40 \mathrm{ml}, 22.4 \mathrm{mmol})$ and $\mathrm{K}_{2} \mathrm{CO}_{3}(4.63 \mathrm{~g}$, $33.6 \mathrm{mmol})$ in acetone $(100 \mathrm{~mL})$ was refluxed for $3 \mathrm{~h}$, filtered and worked-up as above, to afford the title compound as an oil (4.20 g, $22.1 \mathrm{mmol}, 99 \%)$.

3-Chloropropyl 1-methyl-2-imidazolyl (RS)-sulfoxide (6). To a solution of the sulfide (343 mg, $1.81 \mathrm{mmol})$ in $\mathrm{CH}_{2} \mathrm{Cl}_{2}(10 \mathrm{~mL})$ at $0^{\circ} \mathrm{C}$ was added a solution of $\mathrm{mCPBA}(55 \%, 565 \mathrm{mg}$, $1.81 \mathrm{mmol})$ in $\mathrm{CH}_{2} \mathrm{Cl}_{2}(10 \mathrm{~mL})$ over $15 \mathrm{~min}$. Stirring for a further $5 \mathrm{~min}$, followed by work-up as for 1 above, and chromatography (EtOAc) afforded the title compound $\mathbf{6}$ as an orange oil (224 mg, $1.09 \mathrm{mmol}, 60 \%)$. ${ }^{1} \mathrm{H}$ NMR (500 MHz, $\left.\mathrm{CDCl}_{3}\right): \delta 2.21-2.31(2 \mathrm{H}, \mathrm{m}), 3.42(1 \mathrm{H}, \mathrm{dt}, J=$ 13.5, 7.5 Hz), $3.56(1 \mathrm{H}, \mathrm{dt}, J=13.5,7.5 \mathrm{~Hz}), 3.62-3.70(2 \mathrm{H}, \mathrm{m}), 3.93(3 \mathrm{H}, \mathrm{s}), 7.00(1 \mathrm{H}, \mathrm{s}), 7.13$ $(1 \mathrm{H}, \mathrm{s}) . v_{\max }: 2961,1505,1464,1412,1279,1041,764,735,688 \mathrm{~cm}^{-1} \cdot \mathrm{m} / \mathrm{z}(\mathrm{CI}): 206\left(\mathrm{M}^{+}, 100\right)$, $207\left(\mathrm{M}^{+}+\mathrm{H}, 93\right), 208\left(\mathrm{M}^{+}\left({ }^{37} \mathrm{Cl}\right), 42\right), 209\left(\mathrm{M}^{+}+\mathrm{H}\left({ }^{37} \mathrm{Cl}\right), 35\right)$.

Cyclopropyl 1-methyl-2-imidazolyl (RS)-sulfoxide (7). (i) A solution of the sulfoxide 6 $(150 \mathrm{mg}, 0.73 \mathrm{mmol})$ and methyl crotonate $(85 \mu \mathrm{l}, 0.80 \mathrm{mmol})$ in THF $(4 \mathrm{~mL})$ at $-78{ }^{\circ} \mathrm{C}$ was treated with NaHMDS (nominal $1.0 \mathrm{M}, 0.77 \mathrm{~mL}, 0.77 \mathrm{mmol}$ ) over $2 \mathrm{~min}$, and stirred for a further $20 \mathrm{~min}$. Work-up as for 2 above and chromatography (EtOAc) afforded the title compound 7 as an oil (58 mg, $0.34 \mathrm{mmol}, 47 \%) .{ }^{1} \mathrm{H}$ NMR $\left(300 \mathrm{MHz}, \mathrm{CDCl}_{3}\right): \delta 0.85-0.92(1 \mathrm{H}$, $\mathrm{m}), 0.98-1.07(1 \mathrm{H}, \mathrm{m}), 1.11-1.20(1 \mathrm{H}, \mathrm{m}), 1.26-1.35(1 \mathrm{H}, \mathrm{m}), 2.87(1 \mathrm{H}$, apparent $\mathrm{tt}, J=4.8$, $8.0 \mathrm{~Hz}), 3.92(3 \mathrm{H}, \mathrm{s}), 6.98(1 \mathrm{H}, \mathrm{d}, J=1 \mathrm{~Hz}), 7.11(1 \mathrm{H}, \mathrm{d}, J=1 \mathrm{~Hz}) . v_{\max }: 3104,2956,1464$, 1413, 1279, 1045, 877, 780, $690 \mathrm{~cm}^{-1} \cdot \mathrm{m} / \mathrm{z}(\mathrm{CI}): 171\left(\mathrm{M}^{+}+\mathrm{H}, 100 \%\right), 188\left(\mathrm{M}^{+}+\mathrm{NH}_{4}, 8\right)$. HRMS Calcd. for $\mathrm{C}_{7} \mathrm{H}_{10} \mathrm{~N}_{2} \mathrm{OS}+\mathrm{H}^{+}$: 171.0592; Found 171.0586 . 
(ii) A solution of the sulfoxide 6 (434) $(95 \mathrm{mg}, 0.46 \mathrm{mmol})$ in $\mathrm{THF}(2 \mathrm{~mL})$ at $-78{ }^{\circ} \mathrm{C}$ was treated with LiHMDS (nominal 1.0M, $0.51 \mathrm{~mL}, 0.51 \mathrm{mmol}$ ), stirred $30 \mathrm{~min}$ and worked up as above to afford the title compound 7 as an oil (68 $\mathrm{mg}, 0.40 \mathrm{mmol}, 87 \%$ ).

4-Chlorobutyl 1-methyl-2-imidazolyl sulfide. A mixture of 1-methyl-2-imidazolinethiol (2.56 g, $22.4 \mathrm{mmol}$ ), 1-bromo-4-chlorobutane $\left(2.58 \mathrm{~mL}, 22.4 \mathrm{mmol}\right.$ ) and $\mathrm{K}_{2} \mathrm{CO}_{3}$ (4.6 g, 33.6 $\mathrm{mmol})$ in acetone $(100 \mathrm{~mL})$ was heated at reflux for $8 \mathrm{~h}$. The suspension was filtered and the residue was washed with acetone $(2 \times 30 \mathrm{~mL})$. The filtrate was dried over $\mathrm{MgSO}_{4}$, and concentrated in vacuo to yield the crude title compound as an oil, which was not purified before oxidation. ${ }^{1} \mathrm{H} \mathrm{NMR}\left(270 \mathrm{MHz}, \mathrm{CDCl}_{3}\right): \delta 1.78-1.96(4 \mathrm{H}, \mathrm{m}), 3.08(2 \mathrm{H}, \mathrm{t}, J=7 \mathrm{~Hz}), 3.57(2 \mathrm{H}, \mathrm{t}$, $J=6.4 \mathrm{~Hz}), 3.62(3 \mathrm{H}, \mathrm{s}), 6.93(1 \mathrm{H}, \mathrm{d}, J=1.3 \mathrm{~Hz}), 7.05(1 \mathrm{H}, \mathrm{d}, J=1.3 \mathrm{~Hz})$.

4-Chlorobutyl 1-methyl-2-imidazolyl (RS)-sulfoxide (8a). The crude sulfide was dissolved in a 1:1 mixture of methanol and water $(210 \mathrm{~mL})$, and cooled to $0{ }^{\circ} \mathrm{C} . \mathrm{NaIO}_{4}(4.95 \mathrm{~g}, 23 \mathrm{mmol})$ was added in one portion and the suspension was stirred for $48 \mathrm{~h}$. It was filtered and the filtrate was concentrated in vacuo to remove as much methanol as possible. The crude oil was dissolved in water $(100 \mathrm{~mL})$, and extracted with $\mathrm{CHCl}_{3}(400 \mathrm{~mL})$. The combined organic layers were dried and concentrated in vacuo, and the crude product was subjected to flash chromatography (EtOAc) to yield the title compound 8a as an oil, which was dried over several days under vacuum (3.00 g, $13.42 \mathrm{mmol}, 60 \%)$. ${ }^{1} \mathrm{H} \mathrm{NMR}\left(300 \mathrm{MHz}, \mathrm{CDCl}_{3}\right): \delta 1.91-2.04(4 \mathrm{H}, \mathrm{m}), 3.31-$ $3.41(1 \mathrm{H}, \mathrm{m}), 3.42-3.52(1 \mathrm{H}, \mathrm{m}), 3.56-3.61(2 \mathrm{H}, \mathrm{m}), 3.97(3 \mathrm{H}, \mathrm{s}), 7.03(1 \mathrm{H}, \mathrm{d}, J=1.1 \mathrm{~Hz}), 7.16$ $(1 \mathrm{H}, \mathrm{d}, J=1.1 \mathrm{~Hz})$.

Methyl (3RS,4RS,SSR)-7-chloro-3-methyl-4-(1-methyl-2-imidazolylsulfinyl)heptanoate (9). A solution of the sulfoxide $8 \mathbf{a}(208 \mathrm{mg}, 0.95 \mathrm{mmol})$ and methyl crotonate $(0.11 \mathrm{~mL}, 1 \mathrm{mmol})$ in THF (5 mL) was cooled to $-78{ }^{\circ} \mathrm{C}$, and a solution of LiHMDS (180 mg, $\left.1.17 \mathrm{mmol}\right)$ in THF $(1 \mathrm{~mL})$ was added over $2 \mathrm{~min}$. The solution was stirred at $-78{ }^{\circ} \mathrm{C}$ for $20 \mathrm{~min}$, before being quenched with saturated $\mathrm{NHCl}_{4}(4 \mathrm{~mL})$. The solution was warmed to room temperature and water $(4 \mathrm{~mL})$ was added. The mixture was extracted with $\mathrm{CH}_{2} \mathrm{Cl}_{2}(3 \times 20 \mathrm{~mL})$ and the combined organic layers were dried and concentrated in vacuo. The crude product was subjected to flash chromatography (EtOAc) to yield the title compound 9 as an oil (146 mg, $0.46 \mathrm{mmol}, 48 \%$ ). ${ }^{1} \mathrm{H}$ NMR (500 MHz, $\left.\mathrm{CDCl}_{3}\right): \delta 1.20(3 \mathrm{H}, \mathrm{d}, J=7 \mathrm{~Hz}), 1.88-1.98(2 \mathrm{H}, \mathrm{m}), 2.12-2.19(1 \mathrm{H}, \mathrm{m}), 2.37$ $(1 \mathrm{H}, \mathrm{dd}, J=5,7 \mathrm{~Hz}), 2.43-2.52(2 \mathrm{H}, \mathrm{m}), 3.50-3.57(1 \mathrm{H}, \mathrm{m}), 3.58-3.66(1 \mathrm{H}, \mathrm{m}), 3.67(3 \mathrm{H}, \mathrm{s}$, OMe), 3.68-3.85 (1H, m), $3.96(3 \mathrm{H}, \mathrm{s}), 6.99(1 \mathrm{H}, \mathrm{d}, J=0.9 \mathrm{~Hz}), 7.14(1 \mathrm{H}, \mathrm{d}, J=0.9 \mathrm{~Hz})$.

Hexyl 1-methyl-2-imidazolyl sulfide. To a suspension of 1-methyl-2-imidazolinethiol (2.00 g, $17.5 \mathrm{mmol})$ in aqueous $\mathrm{MeOH}(1: 1,60 \mathrm{~mL})$ was added $\mathrm{NaOH}(0.92 \mathrm{~g}, 23 \mathrm{mmol})$, and the resulting solution was stirred for $10 \mathrm{~min}$ at room temperature before a solution of 1-bromohexane (3.16 g, $19 \mathrm{mmol})$ in $\mathrm{MeOH}(10 \mathrm{~mL})$ was added. The mixture was refluxed for $3 \mathrm{~h}$, poured into water, and extracted with $\mathrm{CHCl}_{3}(5 \times 50 \mathrm{~mL})$. The combined extracts were concentrated in vacuo to afford the title compound as a mobile oil (3.50 g, $17.7 \mathrm{mmol}, 101 \%) .{ }^{1} \mathrm{H} \mathrm{NMR}(300 \mathrm{MHz}$, $\left.\mathrm{CDCl}_{3}\right): \delta 0.73(3 \mathrm{H}, \mathrm{t}, J=7 \mathrm{~Hz}), 1.1-1.3(6 \mathrm{H}, \mathrm{m}), 1.50(2 \mathrm{H}$, quintet, $J=7.4 \mathrm{~Hz}), 2.89(2 \mathrm{H}, \mathrm{t}, J=$ $7.4 \mathrm{~Hz}), 3.45(3 \mathrm{H}, \mathrm{s}), 6.76(1 \mathrm{H}, \mathrm{d}, J=1.5 \mathrm{~Hz}), 6.89(1 \mathrm{H}, \mathrm{d}, J=1.5 \mathrm{~Hz})$. 
Hexyl 1-methyl-2-imidazolyl (RS)-sulfoxide (11). A solution of mCPBA (55\%, $5.50 \mathrm{~g}$, $17.5 \mathrm{mmol})$ in $\mathrm{CH}_{2} \mathrm{Cl}_{2}(60 \mathrm{~mL})$ was added at $0{ }^{\circ} \mathrm{C}$ to a solution of the crude sulfide $(3.50 \mathrm{~g}$, $17.7 \mathrm{mmol})$ in $\mathrm{CH}_{2} \mathrm{Cl}_{2}(60 \mathrm{~mL})$ over $1.5 \mathrm{~h}$, and the reaction was poured into dilute aqueous $\mathrm{NaOH}$ after filtration and washing as detailed previously. Concentration and chromatography (EtOAc) afforded the title compound $\mathbf{1 1}$ as a light yellow oil $(3.25 \mathrm{~g}, 15.2 \mathrm{mmol}, 87 \%$ over 2 steps). ${ }^{1} \mathrm{H} \mathrm{NMR}\left(300 \mathrm{MHz}, \mathrm{CDCl}_{3}\right): \delta 0.78(3 \mathrm{H}, \sim \mathrm{t}, J=7 \mathrm{~Hz}), 1.20-1.50(6 \mathrm{H}, \mathrm{m}), 1.59-1.72$ $(2 \mathrm{H}, \mathrm{m}), 3.19(1 \mathrm{H}, \mathrm{ddd}, J=7.8,8.5,13.0 \mathrm{~Hz}), 3.33(1 \mathrm{H}, \mathrm{ddd}, J=6.5,8.3,13.0 \mathrm{~Hz}), 3.86$ $(3 \mathrm{H}, \mathrm{s}), 6.94(1 \mathrm{H}, \mathrm{s}), 7.05(1 \mathrm{H}, \mathrm{s}) . v_{\max }: 3105,2930,2859,1463,1412,1279,1038,914$, $761,686 \mathrm{~cm}^{-1} \cdot \mathrm{m} / \mathrm{z}(\mathrm{CI}): 215\left(\mathrm{M}^{+}+\mathrm{H}, 100 \%\right), 232\left(\mathrm{M}^{+}+\mathrm{NH}_{4}, 8\right)$. HRMS Calcd. for $\mathrm{C}_{10} \mathrm{H}_{18} \mathrm{~N}_{2} \mathrm{OS}+\mathrm{H}^{+}: 215.1218$; Found 215.1210.

Methyl(1RS,2RS)-2-[(1RS,SSR)-1-(1-methyl-2-imidazolylsulfinyl)hexyl]cyclopropane-

carboxylate (12). A solution of the sulfoxide 11 (440 mg, $2.04 \mathrm{mmol})$ in THF (6 mL) was deprotonated with a solution of LiHMDS $(2.44 \mathrm{mmol})$ in THF $(4.5 \mathrm{~mL})$ at $-78{ }^{\circ} \mathrm{C}$ over $10 \mathrm{~min}$. A solution of methyl bromocrotonate $(0.32 \mathrm{~mL}, 2.45 \mathrm{mmol})$ in THF $(4 \mathrm{~mL})$ was added and the mixture was stirred at $-78{ }^{\circ} \mathrm{C}$ for $20 \mathrm{~min}$. Standard work-up and chromatography (EtOAc) afforded the title compound 12 as a pale yellow oil (455 mg, $1.46 \mathrm{mmol}, 72 \%)$. ${ }^{1} \mathrm{H}$ NMR $\left(300 \mathrm{MHz}, \mathrm{CDCl}_{3}\right): \delta 0.31-0.37(1 \mathrm{H}, \mathrm{m}), 0.65-0.85(3 \mathrm{H}, \mathrm{m}), 0.89(1 \mathrm{H}, \mathrm{dt}, J=8.5,4.5 \mathrm{~Hz})$, 1.09-1.55 (8H, m), 1.67-1.88 (2H, m), $2.87(1 \mathrm{H}, \mathrm{ddd}, J=4.3,8.6,10.5 \mathrm{~Hz}), 3.54(3 \mathrm{H}, \mathrm{s}), 3.81$ $(3 \mathrm{H}, \mathrm{s}), 6.91(1 \mathrm{H}, \mathrm{s}), 7.04(1 \mathrm{H}, \mathrm{s}) . v_{\max }: 2955,2860,1730,1462,1348,1278,1208,1174$, $1052 \mathrm{~cm}^{-1} \cdot \mathrm{m} / \mathrm{z}(\mathrm{CI}): 313\left(\mathrm{M}^{+}+\mathrm{H}, 68 \%\right), 297,252,202,130,115,83$. HRMS Calcd. for $\mathrm{C}_{15} \mathrm{H}_{24} \mathrm{~N}_{2} \mathrm{O}_{3} \mathrm{~S}+\mathrm{H}^{+}$: 313.1586; Found 313.1593.

Methyl trans-2-(hex-1-enyl)cyclopropanecarboxylate (13). A solution of the sulfoxide 12 $(2.525 \mathrm{~g}, 8.09 \mathrm{mmol})$ in toluene $(50 \mathrm{~mL})$ was refluxed in the presence of $\mathrm{K}_{2} \mathrm{CO}_{3}(1.340 \mathrm{~g}$, $9.71 \mathrm{mmol})$ for $30 \mathrm{~h}$, poured into water $(100 \mathrm{~mL})$ and extracted with $\mathrm{CH}_{2} \mathrm{Cl}_{2}(5 \times 50 \mathrm{~mL})$. Concentration of the organic layers, followed by chromatography (8:1 petrol:EtOAc) afforded the title compound 13 as an oil (1.324 g, $7.27 \mathrm{mmol}, 90 \%)$ and as a 5.4:1 mixture of $(E)$ - and $(Z)$ isomers. ${ }^{1} \mathrm{H}$ NMR $\left(300 \mathrm{MHz}, \mathrm{CDCl}_{3}\right): \delta 0.81-0.95(3 \mathrm{H}, \mathrm{m}), 1.21-1.45(6 \mathrm{H}, \mathrm{m}), 1.55(1 \mathrm{H}, \mathrm{ddd}, J$ $=3.9,4.9,8.6 \mathrm{~Hz}), 1.90-2.00(2 \mathrm{H}, \mathrm{m}), 2.1-2.2(1 \mathrm{H}, \mathrm{m}), 3.64(3 \mathrm{H}, \mathrm{s}), 4.97(1 \mathrm{H}, \mathrm{ddt}, J=15.3$, $8.3,1 \mathrm{~Hz}), 5.56(1 \mathrm{H}, \mathrm{dt}, J=15.3,6.8 \mathrm{~Hz}) .((Z)$-isomer: $\delta 3.66(3 \mathrm{H}, \mathrm{s}), 4.75(1 \mathrm{H}, \mathrm{ddt}, J=10.8$, 9.6, $1.5 \mathrm{~Hz}), 5.38(1 \mathrm{H}, \mathrm{dt}, J=7.5,10.8 \mathrm{~Hz})$.) $v_{\max }: 2927,2856,1734,1443,1265,1202,1172$, $962 \mathrm{~cm}^{-1} \cdot \mathrm{m} / \mathrm{z}(\mathrm{CI}): 183\left(\mathrm{M}^{+}+\mathrm{H}, 7 \%\right), 200\left(\mathrm{M}^{+}+\mathrm{NH}_{4}, 100\right)$. HRMS Calcd. for $\mathrm{C}_{11} \mathrm{H}_{18} \mathrm{O}_{2}+\mathrm{H}^{+}$: 183.1385; Found 183.1389.

trans-2-(Hex-1-enyl)cyclopropanemethanol (14). To a solution of the ester 13 (1.324 g, $7.27 \mathrm{mmol})$ in THF $(30 \mathrm{~mL})$ at $0{ }^{\circ} \mathrm{C}$ was added $\mathrm{LiAlH}_{4}(553 \mathrm{mg}, 14.5 \mathrm{mmol})$ in small portions over $15 \mathrm{~min}$. The reaction was stirred at $0{ }^{\circ} \mathrm{C}$ for $2 \mathrm{~h}$, quenched carefully with water and poured into dilute brine. Extraction with $\mathrm{CH}_{2} \mathrm{Cl}_{2}(5 \times 50 \mathrm{~mL})$, concentration in vacuo afforded the title compound 14 as a colourless oil $(1.122 \mathrm{~g}, 7.28 \mathrm{mmol}, 100 \%)$, as a 5:1 mixture of $(E)$ - and $(Z)$ isomers. ${ }^{1} \mathrm{H}$ NMR $\left(300 \mathrm{MHz}, \mathrm{CDCl}_{3}\right): \delta 0.52-0.60(2 \mathrm{H}, \mathrm{m}), 0.83-0.92(3 \mathrm{H}, \mathrm{m}), 1.00-1.11(1 \mathrm{H}$, $\mathrm{m}), 1.19-1.50(5 \mathrm{H}, \mathrm{m}), 1.75(1 \mathrm{H}, \mathrm{bs}), 1.9-2.0(2 \mathrm{H}, \mathrm{m}), 3.39-3.55(2 \mathrm{H}, \mathrm{m}), 4.98(1 \mathrm{H}, \mathrm{ddt}, J=$ $15.2,8.3,1.3 \mathrm{~Hz}), 5.46(1 \mathrm{H}, \mathrm{dt}, J=15.2,6.8 \mathrm{~Hz})$. ((Z)-isomer: $\delta 0.65(1 \mathrm{H}, \mathrm{dt}, J=8.5,5.0 \mathrm{~Hz})$, 
2.08-2.16 (2H, m), $4.76(1 \mathrm{H}, \mathrm{ddt}, J=10.7,9.51 .5 \mathrm{~Hz}), 5.28(1 \mathrm{H}, \mathrm{dt}, J=10.7,7.5 \mathrm{~Hz}).) v_{\max }$ : 3340, 3002, 2926, 1465, 1378, 1053, $960 \mathrm{~cm}^{-1} . \mathrm{m} / \mathrm{z}(\mathrm{CI}): 154\left(\mathrm{M}^{+}, 39 \%\right), 172\left(\mathrm{M}^{+}+\mathrm{NH}_{4}, 100\right)$. HRMS Calcd. for $\mathrm{C}_{10} \mathrm{H}_{18} \mathrm{O}+\mathrm{NH}_{4}^{+}$172.1701; Found 172.1690.

trans-2-(Hex-1-enyl)cyclopropanecarbaldehyde (15). ${ }^{10 \mathrm{i}, \mathrm{k}}$ To a suspension of PCC $(860 \mathrm{mg}$, $4.00 \mathrm{mmol}$ ), $\mathrm{NaOAc}(131 \mathrm{mg}, 1.60 \mathrm{mmol})$ and crushed $3 \mathrm{~A}$ molecular sieves $(320 \mathrm{mg})$ in $\mathrm{CH}_{2} \mathrm{Cl}_{2}$ $(12 \mathrm{~mL})$ at room temperature under nitrogen was added a solution of the alcohol 14 (308 $\mathrm{mg}$, $2.00 \mathrm{mmol})$ in $\mathrm{CH}_{2} \mathrm{Cl}_{2}(6 \mathrm{~mL})$. The resulting black suspension was stirred at room temperature for $1.5 \mathrm{~h} . \mathrm{Et}_{2} \mathrm{O}(20 \mathrm{~mL})$ and Celite were added and the mixture was stirred for a further $30 \mathrm{~min}$. The mixture was then filtered through a silica pad, the residue washed with $\mathrm{Et}_{2} \mathrm{O}(3 \times 15 \mathrm{~mL})$ and the organic layers concentrated in vacuo. The residue was chromatographed (12:1 petrol:EtOAc) to afford the title compound 15 as a pungent oil (284 $\mathrm{mg}, 1.87 \mathrm{mmol}, 94 \%)$, as 5:1 mixture of $(E)$ - and $(Z)$-isomers. ${ }^{1} \mathrm{H}$ NMR $\left(300 \mathrm{MHz}, \mathrm{CDCl}_{3}\right): \delta 0.80-0.87(3 \mathrm{H}, \mathrm{m}), 1.09(1 \mathrm{H}$, ddd, $J=4.6,6.5,8.0 \mathrm{~Hz}), 1.20-1.35(4 \mathrm{H}, \mathrm{m}), 1.42(1 \mathrm{H}, \mathrm{dt}, J=8.9,4.8 \mathrm{~Hz}), 1.78(1 \mathrm{H}, \mathrm{m}), 1.92-$ $2.11(3 \mathrm{H}, \mathrm{m}), 4.97(1 \mathrm{H}, \mathrm{ddt}, J=15.2,8.2,1.7 \mathrm{~Hz}), 5.57(1 \mathrm{H}, \mathrm{dt}, J=15.2,6.9 \mathrm{~Hz}), 9.07(1 \mathrm{H}, \mathrm{d}, J$ $=5.1 \mathrm{~Hz}) .((Z)$-isomer: $\delta 2.17-2.27(1 \mathrm{H}, \mathrm{m}), 4.77(1 \mathrm{H}, \mathrm{ddt}, J=10.5,9.5,1.3 \mathrm{~Hz}), 5.40(1 \mathrm{H}, \mathrm{dt}, J$ $=10.6,7.5 \mathrm{~Hz}), 9.15(1 \mathrm{H}, \mathrm{d}, J=4.9 \mathrm{~Hz})$.) $v_{\max }: 2930,2858,1716,1465,1167,1007,964 \mathrm{~cm}^{-1}$. $\mathrm{m} / \mathrm{z}(\mathrm{CI}): 153\left(\mathrm{M}^{+}+\mathrm{H}, 43 \%\right), 170\left(\mathrm{M}^{+}+\mathrm{NH}_{4}, 100\right)$. HRMS Calcd. for $\mathrm{C}_{10} \mathrm{H}_{16} \mathrm{O}+\mathrm{H}^{+}: 153.1279$; Found 153.1283 .

( \pm )-Dictyopterene A (16). To a suspension of methyltriphenylphosphonium bromide $(1.272 \mathrm{~g}$, $3.56 \mathrm{mmol})$ in $\mathrm{Et}_{2} \mathrm{O}(6 \mathrm{~mL})$ was added $1.0 \mathrm{M}$ solution of in THF NaHMDS (3.56 mL, $3.56 \mathrm{mmol}$ ) over $5 \mathrm{~min}$ at room temperature to give a deep yellow suspension. This was stirred at room temperature for $10 \mathrm{~min}$, cooled to $-78{ }^{\circ} \mathrm{C}$ and reacted with the aldehyde $15(\sim 90 \%$, $361 \mathrm{mg}, 2.14 \mathrm{mmol})$ in $\mathrm{Et}_{2} \mathrm{O}(3 \mathrm{~mL})$ for $10 \mathrm{~min}$ at $-78{ }^{\circ} \mathrm{C}$ to give a pale yellow mixture. The reaction was quenched at $-78{ }^{\circ} \mathrm{C}$ with aq. $\mathrm{NaHCO}_{3}(50 \mu \mathrm{l})$, warmed to room temperature, filtered through silica and the residue was washed through with pentane $(2 \times 10 \mathrm{~mL})$. The filtrate and washings was distilled over a $30 \mathrm{~cm}$ Vigreaux column to remove $\mathrm{Et}_{2} \mathrm{O}$ and pentane, and the yellow odourous residue was then distilled at atmospheric pressure using a Kugelrohr apparatus and the fraction boiling at $120-140{ }^{\circ} \mathrm{C}$ was collected, yielding dictyopterene A 16, a highly volatile, odourous material ( $80 \mathrm{mg}, 0.53 \mathrm{mmol}, 25 \%)$, as 5:1 mixture of $(E)$ - and (Z)-isomers. ${ }^{1} \mathrm{H}$ NMR $\left(300 \mathrm{MHz}, \mathrm{CDCl}_{3}\right): \delta 0.71-0.81(2 \mathrm{H}, \mathrm{m}), 0.86(3 \mathrm{H}, \mathrm{t}, J=6.7 \mathrm{~Hz}), 1.24-1.40(6 \mathrm{H}, \mathrm{m})$, 1.92-1.99 (2H, m), $4.84(1 \mathrm{H}, \mathrm{dd}, J=1.7,10.2 \mathrm{~Hz}), 4.95-5.07(2 \mathrm{H}, \mathrm{m}), 5.27-5.45(1 \mathrm{H}, \mathrm{m}), 5.48$ $(1 \mathrm{H}, \mathrm{dt}, J=15.2,6.8 \mathrm{~Hz})$. ((Z)-isomer: $\delta 2.09-2.14(2 \mathrm{H}, \mathrm{m}), 4.78(1 \mathrm{H}, \mathrm{ddt}, J=10.7,9.5,1.5 \mathrm{~Hz})$, $4.81(1 \mathrm{H}, \mathrm{dd}, J=1.7,10.2 \mathrm{~Hz})$.) $\mathrm{m} / \mathrm{z}(\mathrm{CI}): 151\left(\mathrm{M}^{+}+\mathrm{H}, 100 \%\right), 168\left(\mathrm{M}^{+}+\mathrm{NH}_{4}, 32\right)$. HRMS Calcd. for $\mathrm{C}_{11} \mathrm{H}_{18}+\mathrm{H}^{+}$: 151.1487; Found 151.1482.

\section{Acknowledgments}

We gratefully acknowledge financial support from the EPSRC, Avecia Ltd., Enterprise Ireland, the University of Salford, University College Dublin, and Westmeath County Council. MC is 
delighted to acknowledge the unstinting help and wise guidance provided by Professor C. W. Rees, during my first forays into chemical synthesis.

\section{References}

1. $\quad$ Little, R. D.; Dawson, J. R. Tetrahedron Lett. 1980, 21, 2609.

2. Caine, D. Tetrahedron 2001, 57, 2643.

3. (a) Walker, A.J. Tetrahedron: Asymmetry 1992, 3, 961. (b) Carreño, M. C. Chem. Rev. 1995, 95, 1717. (c) Wang, C. C.; Huang, H. C.; Reitz, D. B. Org. Prep. Proced. Intl. 2002, $34,271$.

4. Ghera, E.; Ben-David, Y. Tetrahedron Lett. 1979, 4603.

5. (a) Toru, T.; Nakamura, Takemoto, H.; Ueno, Y. Synlett 1997, 449. (b) Nakamura, S.; Watanabe, Y.; Toru, T. J. Chem. Soc., Perkin Trans. 1 1990, 3403.

6. (a) Casey, M.; Manage, A. C.; Nezhat, L. Tetrahedron Lett. 1988, 29, 5821. (b) Casey, M.; Manage, A. C.; Gairns, R. S. Tetrahedron Lett. 1989, 30, 6919. (c) Casey, M.; Gairns, R. S.; Geraghty, G. M.; Kelly, C. J.; Murphy, P. J.; Walker, A. J. Synlett 2000, 1721. (d) Appelbe, Z.; Casey, M.; Keaveney, C.; Kelly, C. J. Synlett 2002 in press.

7. (a) Casey, M.; Manage, A. C.; Murphy, P. J. Tetrahedron Lett. 1992, 33, 965. (b) Casey, M.; Gairns, R. S.; Walker, A. J. Synlett 2000, 1725.

8. (a) Desmaële, D.; Louvet, J.-M. Tetrahedron Lett. 1994, 35, 2549. (b) Zhou, Z.; Larouche, D.; Bennett, S. M. Tetrahedron 1995, 51, 11623.

9. (a) Moore, R. E.; Pettus, J. A. Jr. Tetrahedron Lett. 1968, 4787. (b) Moore, R. E.; Pettus, J. A. Jr.; Mistysyn, J. J. Org. Chem. 1974, 39, 2201.

10. (a) Ohloff, G.; Pickenhagen, W. Helv. Chim. Acta 1969, 52, 880. (b) Das, K. C.; Weinstein, B. Tetrahedron Lett. 1969, 3459. (c) Jaenicke, L.; Akintobi, T.; Marner, F.-J. Liebigs Ann. Chem. 1973, 1252. (d) Billups, W. E.; Chow, W. Y.; Cross, J. H. J. Chem. Soc., Chem. Commun. 1974, 252. (e) Akintobi, T.; Jaenicke, L.; Marner, F.-J.; Waffenschmidt, S. Liebigs Ann. Chem. 1979, 986. (f) Kajiwara, T.; Nakatomi, T.; Sasaki,Y.; Hatanaka, A. Agric. Biol. Chem. 1980, 44, 2099. (g) Yamada, K.; Tan, H.; Hirota, K. Tetrahedron Lett. 1980, 21, 4873. (h) Colobert, F.; Genet, J.-P. Tetrahedron Lett. 1985, 26, 2779. (i) Grandjean, D.; Pale, P.; Chuche, J. Tetrahedron 1991, 47, 1215. (j) Narjes, F.; Bolte, O.; Icheln, D.; König, W. A.; Schaumann, E. J. Org. Chem. 1993, 58, 626. (k) Itoh, T.; Inoue, H.; Emoto, S. Bull. Chem. Soc. Jpn. 2000, 73, 409.

11. Pitchen, P.; France, C, J.; McFarlane, I. M.; Newton, C. G.; Thompson, D. M. Tetrahedron Lett. 1994, 35, 485.

12. Cotton, H.; Elebring, T.; Larsson, M.; Li, L.; Sörensen, H.; von Unge, S. Tetrahedron: Asymmetry 2000, 11, 3819.

13. Woods, G. F., Jr. Org. Synth. 1955, Coll. Vol. 3, 470. 
14. Craig, D.; Geach, N. J.; Pearson, C. J.; Slawin, A. M. Z.; White, A. J. P.; Williams, D. J. Tetrahedron 1995, 51, 6071. 